\title{
Do Late Phase Hyperbaric and Normobaric Oxygen Therapies Have Effect on Liver Damage? An Experimental Sepsis Model
}

\author{
Atilla Bektas ${ }^{1 *}$, Meltem Ulusoy ${ }^{2}$ and Mehmet Refik Mas ${ }^{3,4}$ \\ ${ }^{1}$ Department of Internal Medicine and Gastroenterology, Akropol Hospital, Turkey; 2Department of Biology, Hacettepe University, Biolog, \\ Turkey; 3Department of Internal Medicine, Dokuz Eylül University, Turkey; 4Department of Health sciences, Eastern Mediterranean \\ University, TRNC
}

\begin{abstract}
Background: Sepsis is fatal presentation which affects many systems with possible progression to organ dysfunction and organ failure. Among these organs liver plays an important role in the prognosis of this syndrome. This study investigated the effects of hyperbaric oxygen ( $\mathrm{HBO}$ ) and normobaric oxygen $(\mathrm{NBO})$ therapies on liver damage and oxidative stress in an experimental sepsis model.
\end{abstract}

Materials and methods: Forty males Wistar rats were randomized into 4 groups as sham group $(n=10)$, control (Sepsis+Cefepime) group $(\mathrm{n}=10), \mathrm{HBO}\left(\right.$ Sepsis $^{+}$Cefepime $\left.+\mathrm{HBO}\right)$ group $(\mathrm{n}=10)$, and $\mathrm{NBO}\left(\right.$ Sepsis ${ }^{+C}$ Cefepime $\left.+\mathrm{NBO}\right)$ group $(\mathrm{n}=10)$. Five days after sepsis induction, animals were sacrificed. The oxidative stress parameters, malondialdehyde (MDA) and superoxide dismutase (SOD) and glutathione peroxidase (GSH-Px) for antioxidant response were measured in liver tissue. Neutrophil migration using myeloperoxidase (MPO) activity and its contribution to liver damage was evaluated.

Results: While MDA levels in $\mathrm{HBO}$ group were found to be lower than those in the control group, and comparable to those in the sham group, no difference was detected in the MDA levels between the control and NBO groups. SOD levels in NBO group were detected to be significantly higher than the control group. GSH-Px enzyme activity in HBO and NBO groups was at similar levels. Even though MPO levels in HBO group appeared to be lower than the control group, the difference did not reach statistical significance. When MPO levels and histopathological examination were evaluated, it was observed that neither $\mathrm{HBO}$ nor $\mathrm{NBO}$ administration in addition to antibiotherapy provided decrease in neutrophil infiltration which has an important role in liver damage.

Conclusion: The benefit of HBO in the treatment of sepsis in addition to the use of antibiotics has also been confirmed to be successful in this study. Furthermore the data obtained from NBO applications in this study, is thought to be potentially useful for sepsis treatment.

Keywords: Hyperbaric oxygen therapy; Normobaric oxygen therapy; Oxidative stress; Liver; Sepsis

\section{INTRODUCTION}

Sepsis is a complex syndrome affecting many systems with progression to shock, organ dysfunction, organ failure and death by causing hemodynamic changes in particular [1-3]. Lifethreatening organ dysfunction after impaired response of host against infection is implicated in this process $[4,5]$. Several bacterial agents are implicated in sepsis etiology. While the most frequent agents causing sepsis before antibiotics became available were Streptococci and Staphylococci, with the use of antibiotics, gram negative bacteria started to be isolated at increasingly more rates as the cause of sepsis $[6,7]$.

Bacterial antigenic structures initiate the release of many mediators (cytokines) from endothelial cells and other cells $[6,8,9]$. The target organ is the vascular endothelium. When endothelial damage occurs, organ perfusion is impaired and organ failure occurs [10,11]. The most common findings in the sepsis are pulmonary, renal, intestinal, hepatic and heart failure $[6,9,12]$.

Liver is believed to play a key role in sepsis as an active player and affected organ of the syndrome [13]. Hepatic damage in sepsis is

Correspondence to: Atilla Bektas, Department of Internal Medicine and Gastroenterology, Akropol Hospital, Turkey, Tel: 00905058745426; E-mail: atillabektas2000@yahoo.com

Received: February 17, 2018;; Accepted: March 20, 2019; Published: March 27, 2019

Citation: Bektas A, Ulusoy M, Mas MR (2019) Do Late Phase Hyperbaric And Normobaric Oxygen Therapies Have Effect On Liver Damage?: An Experimental Sepsis Model. Gen Med (Los Angeles) 7:324 doi: 10.24105/2327-5146.7.324

Copyright: (c) 2019 Bektas A, et al. This is an open-access article distributed under the terms of the Creative Commons Attribution License, which permits unrestricted use, distribution, and reproduction in any medium, provided the original author and source are credited. 
caused by the reduced hepatic arterial blood flow due to septic shock [14]. Together with all these events in sepsis, a generalized oxidative stress occurs due to increased free radicals in the body $[2,11,15]$. The major antioxidant enzymes directly involved in the neutralization of reactive oxygen species (ROS) and reactive nitrogen species (RNS) are: Superoxide dismutase (SOD), catalase (CAT), glutathione peroxidase (GPx) and glutathione reductase (GRx) [15]. The other hand, Malondialdehyde (MDA) is the most frequently used biomarker of oxidative stress in many health problems such as cancer, psychiatry, chronic obstructive pulmonary disease, asthma, or cardiovascular diseases $[15,16]$. In addition, MPO in neutrophils is commonly used as a marker of neutrophil infiltration and MPO levels in sepsis are shown in height [17].

Hyperbaric oxygen $(\mathrm{HBO})$ administration is a treatment modality which was developed to prevent oxidative damage [18]. HBO has been shown to be beneficial as monotherapy or adjuvant therapy $[19,20]$ in sepsis treatment [2]. Though there are no comparative trials in sepsis, there are some studies suggesting these benefits may also be obtained with normobaric oxygen (NBO) administration instead of $\mathrm{HBO}$ administration which bears difficulties regarding its use under intensive care conditions [21].

This study investigated the late phase effects of $\mathrm{HBO}$ and $\mathrm{NBO}$ therapies administered in addition to the anti-biotherapy as the current backbone sepsis therapy on liver damage which has a key role in sepsis in rats with sepsis induced by bacterial inoculation method.

\section{METHODS}

With the decision numbered $09 / 4 \mathrm{~K}$ of Ethics Committee of Gulhane Faculty of Medicine, research and development department, 40 healthy, young-adult, male Wistar rats with the weights between 300 and 400 grams were used. Animals were kept under same laboratory conditions throughout the study and fed with commercial rat feed and normal tap water.

\section{Administration of $\mathrm{HBO}$ and $\mathrm{NBO}$ oxygen therapy}

For $\mathrm{HBO}$ and $\mathrm{NBO}$ administration, specially designed and manufactured cylindrical high-pressure chamber with the diameter of $40 \mathrm{~cm}$ and length of $60 \mathrm{~cm}$ with a nickel-chromium steel body tested for its resistance against 10 ATA pressure was used. For $\mathrm{HBO}$, a pressure of 2.4 ATA was applied, and for $\mathrm{NBO}$ a pressure of 1 ATA was applied [22]. Rats were divided into four groups using 'simple random sampling' method.

\section{Sham group (Sham) $(\mathrm{n}=10)$}

Intraperitoneal (IP) normal saline was administered at an equal volume to Escherichia coli given for sepsis induction.

\section{Control group (Sepsis+Cefepime) $(n=10)$}

Following sepsis induction, $50 \mathrm{mg} / \mathrm{kg}$ cefepime via IP route was given twice a day with no additional therapy [21].

\section{NBO group (Sepsis + Cefepime + NBO) $(n=10)$}

Following sepsis induction, $50 \mathrm{mg} / \mathrm{kg}$ cefepime via IP route was given twice a day together with $\mathrm{NBO}(5 \mathrm{~L} / \mathrm{min} 2.2 \times 90 \mathrm{~min} /$ day, 5 day) therapy [21].

\section{HBO group (Sepsis + Cefepime + NBO) $(n=10)$}

Following sepsis induction, $50 \mathrm{mg} / \mathrm{kg}$ cefepime via IP route was given twice a day together with HBO (at 2.4 ATA, $2 \times 90 \mathrm{~min} /$ day, 5 day) therapy. Five days after sepsis induction, animals were sacrificed and liver tissue samples were collected.

\section{Sepsis induction}

E. coli ATCC 25922 strain $\mathrm{H} 110$ was used in the experiment. $1 \mathrm{cc}$ of E. coli bacilli (ATCC 25922)/ml). The rats in the sepsis groups were given $1 \mathrm{ml} \mathrm{SF} \mathrm{IP} \mathrm{containing} 2.1 \times 109 \mathrm{CFU}$ live E. coli. The sepsis table was confirmed by rectal temperature increase, respiratory rate and pulse rate. Rats in sepsis-induced groups (Control, NBO, $\mathrm{HBO}$ ) were given $50 \mathrm{mg} / \mathrm{kg}$ cefepime IP twice daily after induction of sepsis [23].

Preparation of liver tissue: The hepatic tissue levels of malondialdehyde (MDA) for lipid peroxidation, and superoxide dismutase (SOD) and glutathione peroxidase (GSH-Px) for antioxidant response were measured. Neutrophil migration using myeloperoxidase (MPO) activity and its contribution to liver damage was planned to be evaluated [24]. First, animals were taken to ketamine-xylazine anesthesia. While on the one hand, blood was collected from the vena cava with a syringe, while the right ventricle was injected with $\mathrm{NaCI}$ (normal saline). The extracted liver was again washed out in cold normal saline and removed from blood debris and placed in pre-labeled plastic ependorf tubes and placed in a liquid nitrogen tank to be stored at $-80^{\circ} \mathrm{C}$ at the end of the treatment [25].

\section{Biochemical analysis}

Malondialdehyde (MDA) measurement: MDA measurement was performed using the method described by Okhawa et al. For this purpose, $10 \%$ tricloracetic acid (TCA) and $0.675 \%$ thiobarbituric acid (TBA) were used. A $0.5 \mathrm{ml}$ sample (homogenate) was added to $10 \%$ TCA and vortexed. Then the samples were incubated at $90^{\circ} \mathrm{C}$ for 15 minutes. The samples were centrifuged at $3000 \mathrm{rpm}$ for 20 $\mathrm{min}$. After that, $2 \mathrm{ml}$ supernatants were added to $1 \mathrm{ml} 0.675 \%$ TBA and vortexed. The samples were incubated at $90^{\circ} \mathrm{C}$ for 15 minutes. After an incubation period of 15 minutes at $90^{\circ} \mathrm{C}$, the samples were absorbance at $530 \mathrm{~nm}$ was measured using a spectrophotometer. The extinction coefficient $(1.56 \times 105 \mathrm{~cm}-1 \mathrm{M}-1)$ of the TBA-MDA complex was used in the calculation [26].

Superoxide Dismutase Measurement (SOD): SOD measurement was performed using the method described by Sun et al. This method is based on the principle of determining the formation of blue colored formazon at $560 \mathrm{~nm}$ in the spectrophotometer. Therefore, reagent consisting $0.3 \mathrm{mmol} / 1$ xanthine, $0.6 \mathrm{mmol} / \mathrm{l}$ EDTA, $150 \mu \mathrm{mol} / \mathrm{l} \mathrm{NBT}, 400 \mathrm{mmol} / 1 \mathrm{Na}_{2} \mathrm{CO}_{3}$ and $1 \mathrm{~g} / \mathrm{l}$ bovine serum albumin (BSA) were prepared for measuring. Then 0.8 $\mathrm{mmol} / \mathrm{l} \mathrm{CuCl}_{2}, 2 \mathrm{M}\left(\mathrm{NH}_{4}\right) 2 \mathrm{SO}_{4}$ (Ammonium sulphate) were prepared and $167 \mathrm{U} / 1$ xanthine oxidase $(\mathrm{XO})$ were prepared in ammonium sulphate. The supernatants were obtained by centrifugation at $3220 \mathrm{rpm}$ for $30 \mathrm{~min}$ at $+6^{\circ} \mathrm{C}$. Supernatants and chloroform-ethanol solution were mixed in a $1: 1$ ratio and then vortexed [27]. The samples were centrifuged at $3220 \mathrm{rpm}$ at $+4^{\circ} \mathrm{C}$ for $40 \mathrm{~min}$. $50 \mu \mathrm{l}$ of samples were added to $1425 \mu \mathrm{l}$ measuring reagent and $25 \mu \mathrm{l} 167 \mathrm{U} / 1 \mathrm{XO}$. Blind tube was prepared. Following 
the incubation period of 20 minutes at $25^{\circ} \mathrm{C}, 200 \mu \mathrm{l}$ of samples, and $100 \mu \mathrm{l} 0.08 \mathrm{mM} / \mathrm{C} \mathrm{CuCl}_{2}$ were added to Elisa Reader plate. Then the plate was absorbance at $560 \mathrm{~nm}$ was measured using an Elisa Reader. The absorbance values were calculated by adding the following formula:

$[((\mathrm{K}-\mathrm{N}) / \mathrm{N}) \times \mathrm{D} \times 20] / \mathrm{E}=\mathrm{U} /$ g-protein

In this formula: $\mathrm{K}$, the absorbance of the blind; $\mathrm{N}$, sample absorbance; D, the amount of dilution; E, the amount of extract protein $(\mathrm{g} / \mathrm{ml})$.

Glutathione peroxidase (GSH-Px) measurement: GSH measurement was performed using the method described by Paglia et al. In this method GSH-Px buffer $(50 \mathrm{mM}$ phosphate buffer $\mathrm{pH} 7$ and $5 \mathrm{mM}$ EDTA), $3.2 \mathrm{M}\left(\mathrm{NH}_{4}\right) 2 \mathrm{SO}_{4}, 150 \mathrm{mM}$ reduced glutathione (GSH), $8 \mathrm{mM}$ reductive $\mathrm{NADPH}, 1 \mathrm{M} \mathrm{NaN}_{3}$ (Sodium Azide), GSHReductase enzyme and $2 \mathrm{mM} \mathrm{H}_{2} \mathrm{O}_{2}$ were prepared. After an incubation period of 30 minutes at $25^{\circ} \mathrm{C}, 290 \mu \mathrm{l}$ of samples and $10 \mu \mathrm{l} 2 \mathrm{mM} \mathrm{H}_{2} \mathrm{O}_{2}$ were added to Elisa reader plate. Then the plate was absorbance at $340 \mathrm{~nm}$ was measured using an Elisa Reader. Values were expressed as U/g-protein [28].

Myeloperoxidase (MPO) activity measurement: The extracts required for MPO measurement were obtained as follows; the homogenates were centrifuged at $3220 \mathrm{rpm}$ for 30 minutes at $+6^{\circ} \mathrm{C}$. Supernatants were used to. Samples for MPO measurement were studied with USCNLIFE ELISA KIT (USCN LIFE SCIENCE INC. WUHAN). The results were determined as U/L.

\section{Statistical analysis}

All statistical analyses were conducted using SPSS 11.0 (SPSS Inc., Chicago, IL., USA) statistics package software. Analysis was performed using "Kruskal Wallis" test, followed by, "Mann Whitney-U" test for the pairwise comparison of groups with significant results. In this study "Hepatic Injury Severity Scoring" was used to grade hepatic tissue damage in histopathological examination [29].

\section{RESULTS}

MDA level in the control $(0.43 \pm 0.11 \mathrm{mmol} / \mathrm{g}$ protein $)$ and NBO groups $(0.39 \pm 0.09 \mathrm{mmol} / \mathrm{g}$ protein $)$ was detected to be higher than the sham group $(0.29 \pm 0.04 \mathrm{mmol} / \mathrm{g}$ protein $)(\mathrm{p}<0.05)$. While MDA levels in HBO group $(0.33 \pm 0.05 \mathrm{mmol} / \mathrm{g}$ protein) were found to be lower than the control group $(\mathrm{p}<0.05)$ and comparable to the sham group, no difference was detected between the control and NBO groups (Table 1).

SOD levels in the control $(61.39 \pm 14.88 \mathrm{U} / \mathrm{g}$ protein $)$ and NBO groups $(70.48 \pm 11.48 \mathrm{U} / \mathrm{g}$ protein) were found to be higher than the sham group $(39.59 \pm 7.82 \mathrm{U} / \mathrm{g}$ protein) $(\mathrm{p}<0.05)$. SOD levels in $\mathrm{NBO}$ group $(47.88 \pm 9.34 \mathrm{U} / \mathrm{g}$ protein) were detected to be significantly higher than those in the control groups (Figure 1 and Table 1) $(\mathrm{p}<0.05)$. GSH-Px levels in the control $(73.50 \pm 16.79$ $\mathrm{U} / \mathrm{g}$ protein) and $\mathrm{HBO}$ groups $(64.64 \pm 12.62 \mathrm{U} / \mathrm{g}$ protein) were found to be higher than the sham group $(55.03 \pm 8.07 \mathrm{U} / \mathrm{g}$ protein $)$ ( $\mathrm{p}$ <0.05). GSH-Px enzyme activity levels in HBO (68.79 \pm 10.94 $\mathrm{U} / \mathrm{g}$ protein) and $\mathrm{NBO}$ groups were determined to be comparable (Figure 2 and Table 1).

MPO levels in the control $(13.30 \pm 2.77 \mathrm{U} / \mathrm{L}), \mathrm{HBO}(12.53 \pm 2.54$ $\mathrm{U} / \mathrm{L})$ and NBO groups $(14.65 \pm 2.42 \mathrm{U} / \mathrm{L})$ were detected to be higher than the sham group $(6.55 \pm 1.94 \mathrm{U} / \mathrm{L})(\mathrm{p}<0.05)$. While $\mathrm{MPO}$ levels in $\mathrm{HBO}$ group appeared to be lower than the control group, the difference did not reach statistical significance. While MPO levels in NBO group appeared to be higher than in the control group, no statistically significant difference was detected between the groups. On the other hand MPO levels in HBO group were found to be significantly lower than in NBO group $(\mathrm{p}<0.05)$ (Table 1).

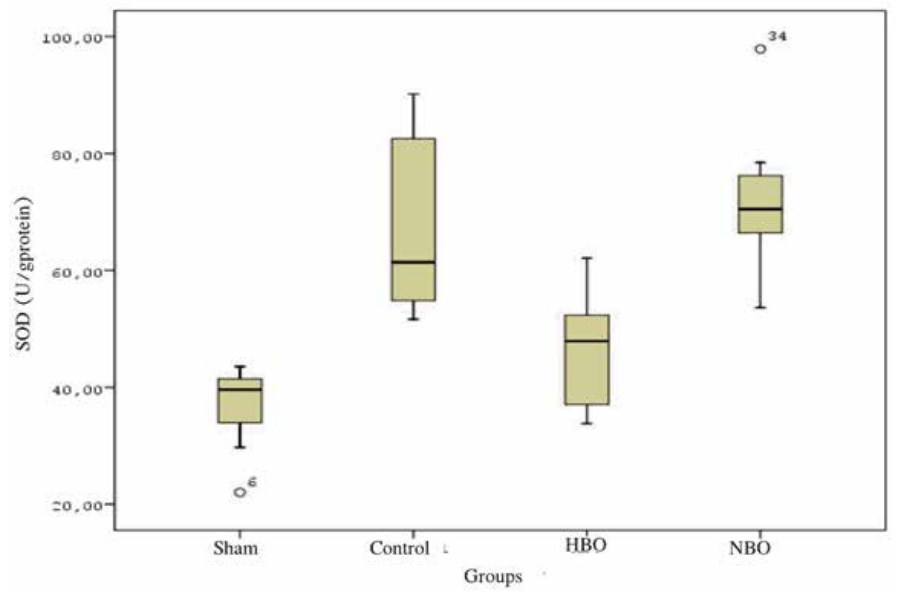

Figure 1: Comparison of SOD levels in all groups.

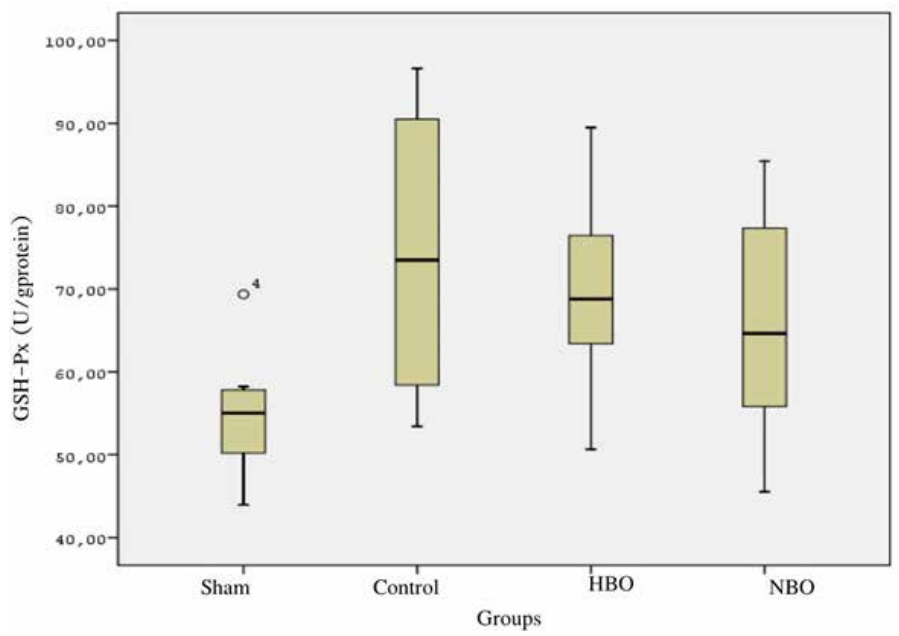

Figure 2: Comparison of GSH-PX levels in all groups.

Table 1: Oxidant-antioxidant status and MPO activity in liver tissue SOD, GSH-PX, MDA.

\begin{tabular}{|c|c|c|c|c|}
\hline Groups & MDA (mmol/g protein) & SOD (U/g protein) & GSH-Px (U/g protein) & MPO (U/L) \\
\hline Sham & $0.29 \pm 0.04$ & $39.59 \pm 7.82$ & $55.03 \pm 8.07$ & $6.55 \pm 1.94$ \\
\hline Control & $0.43 \pm 0.11 \mathrm{a}$ & $61.39 \pm 14.88 \mathrm{a}$ & $73.50 \pm 16.79 \mathrm{a}$ & $13.30 \pm 2.77 \mathrm{a}$ \\
\hline HBO & $0.33 \pm 0.05 \mathrm{~b}, \mathrm{~d}$ & $47.88 \pm 9.34 \mathrm{~b}, \mathrm{~d}$ & $68.79 \pm 10.94 \mathrm{c}$ & $12.53 \pm 2.54 \mathrm{c}, \mathrm{d}$ \\
\hline NBO & $0.39 \pm 0.09 \mathrm{c}$ & $70.48 \pm 11.48 \mathrm{c}$ & $64.64 \pm 12.62$ & $14.65 \pm 2.42 \mathrm{c}$ \\
\hline
\end{tabular}

$\mathrm{p}<0.05$, significant decrease in $\mathrm{HBO}$ group compared to the control group, $\mathrm{p}<0.05$, significant increase in $\mathrm{HBO}$ and NBO groups compared to the sham group, $\mathrm{p}<0.05$, significant decrease in $\mathrm{HBO}$ group compared to NBO group, $\mathrm{p}<0.05$, significant decrease in $\mathrm{HBO}$ group compared to NBO group 


\section{Histopathological examination}

When sepsis-induced groups (Control, HBO, NBO) were evaluated, while a decrease was observed in total damage in $\mathrm{HBO}$ and $\mathrm{NBO}$ groups in terms of inflammation and liver damage, the difference was not statistically significant (Table 2 and Figure 3). No difference was detected between the control group and sepsis-induced groups.

Table 2: Evaluation of the hepatic injury severity scoring (aneurysm, inflammation and congestion/sinusoidal dilation scores) of liver.

\begin{tabular}{|c|c|c|c|c|}
\hline Evaluation & $\begin{array}{l}\text { Sham } \\
(n=10)\end{array}$ & $\begin{array}{c}\text { Control } \\
(n=10)\end{array}$ & $\begin{array}{l}\text { HBO } \\
(n=10)\end{array}$ & $\begin{array}{l}\text { NBO } \\
(n=10)\end{array}$ \\
\hline Aneurysm (score) & 0 & 1 & 0 & 4 \\
\hline Aneurysm & 0 & $0(0-1) a$ & 0 & $0(0-1) \mathrm{a}$ \\
\hline \multicolumn{5}{|l|}{ [Median (Minimum-Maximum)] } \\
\hline \multicolumn{5}{|l|}{ Inflammation } \\
\hline Portal (score) & 0 & 8 & 7 & 6 \\
\hline Parenchymal (score) & 0 & 1 & 3 & 4 \\
\hline Total inflammation & 0 & $1(0-2) \mathrm{a}$ & $1(0-2) a$ & $1(0-2) a$ \\
\hline \multicolumn{5}{|l|}{ [Median (Minimum-Maximum)] } \\
\hline $\begin{array}{l}\text { Congestion/sinusoidal dilation } \\
\text { (score) }\end{array}$ & 0 & 1 & 2 & 1 \\
\hline Congestion/sinusoidal dilation & 0 & $0(0-1) \mathrm{a}$ & $0(0-1) \mathrm{a}$ & $0(0-1) \mathrm{a}$ \\
\hline \multicolumn{5}{|l|}{ [median (minimum-maximum)] } \\
\hline Total damage & 0 & $1(0-4) \mathrm{a}$ & $1(0-2) a$ & $1(1-3) \mathrm{a}$ \\
\hline
\end{tabular}

[Median (Minimum-Maximum)]

${ }^{a} \mathrm{p}<0.05$, significant increase in the control, $\mathrm{HBO}$ and $\mathrm{NBO}$ groups compared to the sham group.

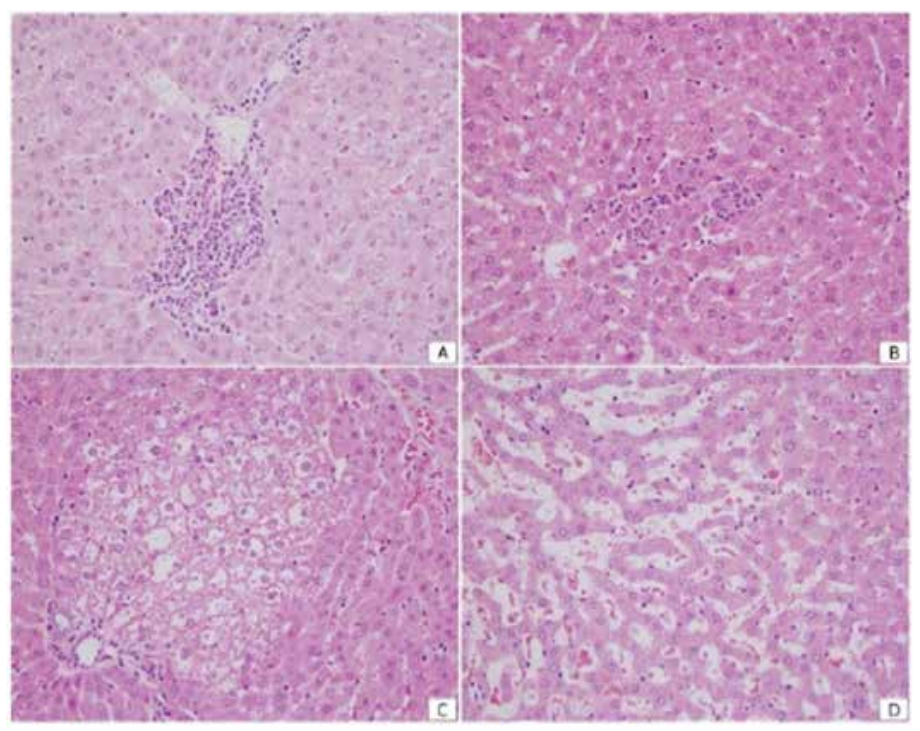

Figure 3: Histopathologic evaluation of liver damage. In portal area, inflammatory cell infiltration is observed containing lymphocytes as majority, and also very few PMN leukocytes (A) In parenchyma, "spotty" necrosis focus containing inflammatory cells and surrounding damaged hepatocytes (B) Apparent local hepatocyte aneurysm is observed starting adjacent to portal area (bottom left corner) and containing all zones until central vein (top right corner) (C) Apparent sinusoidal dilation (D) (400X magnification, Hemotoxilen\& Eosine).

\section{DISCUSSION}

In sepsis patients, alleviating liver damage and restoring liver function decrease the morbidity and mortality rates [13]. Liver dysfunction after sepsis is considered to be a risk factor independent from mortality induced by multiple organ dysfunction syndrome and sepsis [13]. When viewed from this aspect, many investigators are seeking adjuvant therapy in addition to specific anti-biotherapy for the treatment of sepsis [5].

Sepsis models using live bacteria have several advantages. The strain and infecting dose of bacteria can easily be standardized. In addition, the host immune response is directed at the whole microbe. As with endotoxin models, bacterial infection models can be manipulated to produce more clinically relevant results. Irrespective of limitations, these models have proven useful and provide insights into mechanisms of the host response to pathogens 3. A controlled inoculation model was preferred for sepsis induction. The most commonly used bacterium in this model is E. coli. For this reason E. coli ATCC 25922 strain H110 was used in the experiment $[30,31]$.

Studies regarding $\mathrm{HBO}$ as adjuvant therapy in sepsis have also been performed in the past, and its beneficial effects have been reported [12,32]. The role of cellular oxidative damage in multiple organ dysfunction syndrome is well-known. When overly produced or inadequately cleared ROS directly attack lipid and protein structures in biological membranes and impair the membrane structure [33]. In our study, MDA levels were detected to be high in the control and in $\mathrm{NBO}$ groups, and comparable in $\mathrm{HBO}$ and the sham groups. Those results show that $\mathrm{HBO}$ administration in sepsis in addition to antibiotherapy decreases lipid peroxidation and oxidative damage.

Evidence demonstrating the association of endotoxemia, sepsis and septic shock with the formation and release of ROSs reveal that ROSs play an important role in sepsis and/or septic shock [34]. Gram negative bacteria such as E. coli increase oxygen consumption via lipopolysaccharides, activated neutrophils, TNFand other cytokines, and cause ROS formation [35]. Markers of oxidative stress measured from the peripheral venous samples is poorly reflective of hepatic tissue oxidative stress. Therefore, we measured oxidative stress markers in liver tissue [36]. It is wellknown that $\mathrm{HBO}$ administration increases both ROS formation and antioxidant enzymes [37]. In our study, increased activity of both SOD and GSH-Px was detected in sepsis-induced groups (Control, HBO, NBO). This result may be considered as the increase in antioxidant enzymes to remove ROSs formed in sepsis. SOD levels in this NBO group were found to be higher than those in the control group. MDA values in $\mathrm{HBO}$ group and NBO group were observed to be close to each other. Together with the fact that MDA levels are also lower in HBO group compared to the control and NBO groups, it can be explained by the lesser oxidative damage in $\mathrm{HBO}$ group and the fact that the evaluation was performed 5 days after the induction, thereby, reflects late phase data.

Liver appears to be a strong sweeper of the circulating bacteria and their products, and in E. coli bacteremia, neutrophil accumulation in liver sinusoids is well-known [38]. A new study has shown apparent polymorphonuclear leukocyte infiltration in liver cause by E. coli lipopolysaccharides [39-41]. As a main potential site for ROS 
production, neutrophils play an important role in the development of oxidative stress. Neutrophils activate Kupffer cells by causing oxidative stress, and contribute to microvascular dysfunction and edema formation. Found in neutrophils, MPO is widely used as a marker of neutrophil infiltration and the MPO levels have been shown to be elevated in severe inflammatory processes such as sepsis

In support of those results, MPO levels were also higher in sepsisinduced groups in our study. In HBO group the MPO levels were detected to be lower than the control group though no statistically significant difference was observed and detected to be lower than the MPO levels of NBO group.

\section{CONCLUSION}

In rats with sepsis even though $\mathrm{HBO}$ and $\mathrm{NBO}$ administration in addition to antibiotherapy induced by controlled inoculation method using E. coli did not provide adequate histological recovery it was observed that $\mathrm{HBO}$ treatment reduced oxidative liver tissue damage. SOD levels in this NBO group were found to be higher than those in the control group. Studies aiming longer periods of histological recovery follow-up are needed. In NBO group the MDA and GSH-Px values were detected to be similar to those in the $\mathrm{HBO}$ group. In this study the benefit of using $\mathrm{HBO}$ in addition to the use of antibiotics has also been confirmed. Furthermore, the data obtained from NBO applications in this study, is thought to be potentially, as well. NBO administration which is an alternative choice in the treatment of sepsis happens to be easier and less invasive procedure. Nevertheless, additional clinical studies are still needed for this specific subject.

\section{ETHICS COMMITTEE APPROVAL}

Ethics committee approval was received for this study from the Institutional Ethics Committee.

\section{INFORMED CONSENT}

N/A.

\section{AUTHOR CONTRIBUTIONS}

Concept-Atilla Bektas, Mehmet Refik Mas; Design-Atilla Bektas, Mehmet Refik Mas; Supervision-Mehmet Refik Mas; Data Collection and/or Processing-Atilla Bektas, Meltem Ulusoy, Mehmet Refik Mas; Analysis and/or Interpretation-Atilla Bektas, Meltem Ulusoy, Mehmet Refik Mas; Literature Search-Atilla Bektas, Meltem Ulusoy, Mehmet Refik Mas; Writing ManuscriptAtilla Bektas, Mehmet Refik Mas; Critical Review-Atilla Bektas, Mehmet Refik Mas.

\section{CONFLICT OF INTEREST}

The authors have no conflict of interest to declare.

\section{FINANCIAL DISCLOSURE}

The authors declared that this study has received no financial support.

\section{REFERENCES}

1. Angus DC, Linde-Zwirble WT, Lidicker J, Clermont G, Carcillo J, Pinsky MR, et al. Epidemiology of severe sepsis in the United States: Analysis of incidence, outcome, and associated costs of care. Crit Care Med. 2001;29: 1303-1310.

2. Polat G, Ugan RA, Cadirci E, Halici Z. Sepsis and septic shock: Current treatment strategies and new approaches. Eurasian J Med. 2017; 49: 53.

3. Nesseler N, Launey Y, Aninat C, Morel F, Mallédant Y, Seguin P, et al. Clinical review: The liver in sepsis. Crit care. 2012;16: 235.

4. Singer M, Deutschman CS, Seymour CW, Shankar HM, Annane D. The third international consensus definitions for sepsis and septic shock (Sepsis-3). JAMA. 2016;315: 801-810.

5. Rello J, Valenzuela-Sanchez F, Ruiz-Rodriguez M, Moyano S. Sepsis: A review of advances in management. Adv Ther. 2017;34: 2393-2411.

6. Bone RC. Gram positive organisms and sepsis. Arch Intern Med. 1994;154: 26-34

7. Martin MA. Epidemiology and clinical impact of gram negative sepsis. Infect Dis Clin North Am. 1991;5: 739-752.

8. Lynn W. Sepsis In: Infectious diseases AD, (3rd edn) Mosby, London. 1991;pp: 1-14.

9. Bone RC. The pathogenesis of sepsis. Ann Intern Med. 1991;115: 457 469.

10.De-Oliveira TH, Amorin AT, Rezende IS, Barbosa MS, Martins HB, Brito AK, et al. Sepsis induced by Staphylococcus aureus: Participation of biomarkers in a murine model. Int J Exp Clin Med. 2015;21: 345.

11. Cunneen J, Cartwright M. The puzzle of sepsis fitting the pieces of the inflammatory response with treatment. AACN Adv Crit Care. 2004; 15: 18-44.

12. Oter S, Edremitlioglu M, Korkmaz A, Coskun O, Kilic D, Kisa U, et al. Effects of hyperbaric oxygen treatment on liver functions, oxidative status and histology in septic rats. Intensive Care. 2005;31: 1262-1268.

13.Yan J, Li S, Li S. The role of the liver in sepsis. Int Immunol Rev. 2014;33: 498-510.

14. Iskander KN, Osuchowski MF, Stearns KDJ, Kurosawa S, Stepien D, Valentine C, et al. Sepsis: Multiple abnormalities, heterogeneous responses, and evolving understanding. Physiol Rev. 2013;93: 1247 1288.

15.Pham HLA, He H, Pham-HC. Free radicals, antioxidants in disease and health. Int J Biomed Sci. 2008;4: 89.

16. Ansarin K, Khoubnasabjafari M, Jouyban A. Reliability of malondialdehyde as a biomarker of oxidative stress in psychological disorders. Bioimpacts. 2015;5: 123-127.

17. Johnson JL, Hong H, Monfregola J, Catz SD. Increased survival and reduced neutrophil infiltration of the liver in Rab27a-but not Munc 13-4-deficient mice in lipopolysaccharide-induced systemic inflammation. Infect Immun. 2011;79: 3607-3618.

18. Hampson NB. Hyperbaric oxygen: A plea for uniform nomenclature. J Undersea Hyperb Med. 1999;26: 267.

19. Kindwall EP. Hyperbaric oxygen. Br Med J. 1993;307: 515.

20.Tibbles PM, Edelsberg JS. Hyperbaric oxygen therapy. N Engl J Med. 1996;334: 1642-1648.

21. Ozturk A, Yamanel L, Ozenc S, Ince M, Simsek K, Comert B, et al. Comparison of the effects of hyperbaric oxygen and normobaric oxygen on sepsis in rats. Arch of Clin Exp Surg. 2016;5: 7-12.

22.Lutz J, Stark M. Administration of perfluorochemicals under hyperbaric oxygen pressure and treatment with free oxygen radical scavengers. Biomaterials Artif Cells Artif Organs. 1988;16: 395-402. 
23.Kim KS, Bayer AS. Efficacy of BMY-28142 in experimental bacteremia and meningitis caused by Escherichia coli and group B streptococci. Antimicrob Agents Chemother. 1985;28: 51-54.

24.Şener G, Toklu H, Kapucu C, Ercan F, Erkanlı G, Kaçmaz A, et al. Melatonin protects against oxidative organ injury in a rat model of sepsis. Surg Today. 2005;35: 52-59.

25.Etlik Ö, Tomur A, Dündar K, Erdem A, Gündogan NU. The effect of antioxidant vitamins $\mathrm{E}$ and $\mathrm{C}$ on lipoperoxidation of erythrocyte membranes during hyperbaric oxygenation. J Basic Clin Physiol Pharmacol. 1997; 8: 269-278.

26. Khalil MM, Salem A. Lipid peroxidation products in pleural fluid for separation of transudates and exudates. Clin Chem. 1995;41: 13141315.

27. Sun YI, Oberley LW, Li Y. A simple method for clinical assay of superoxide dismutase. Clin Chem. 1988;34: 497-500.

28.Paglia DE, Valentine WN. Studies on the quantitative and qualitative characterization of erythrocyte glutathione peroxidase. J Lab Clin Med. 1967;70: 158-169.

29. Muftuoglu MT, Aktekin A, Ozdemir NC, Saglam A. Liver injury in sepsis and abdominal compartment syndrome in rats. Surg Today. 1967;36: 519-524.

30. Oter S, Edremitlioglu M, Korkmaz A, Coskun O, Kilic D. Effects of hyperbaric oxygen treatment on liver functions, oxidative status and histology in septic rats. Intensive Care Med. 2005;31: 1262-1268.

31. Nemzek JA, Hugunin K, Opp MR. Modeling sepsis in the laboratory: Merging sound science with animal well-being. Comp Med. 2008;58: 120-128.

32.Bærnthsen NF, Hansen MB, Wahl AM, Simonsen U, Hyldegaard O. Treatment with $24 \mathrm{~h}$-delayed normo-and hyperbaric oxygenation in severe sepsis induced by cecal ligation and puncture in rats. J Inflamm. 2017; 14: 27.

33.Kurutas EB. The importance of antioxidants which play the role in cellular response against oxidative/nitrosative stress: Current state Nutr J. 2015;15: 71 .

34.Liaw WJ, Chen TH, Lai ZZ, Chen SJ, Chen A, Tzao C, et al. Effects of a membrane-permeable radical scavenger, Tempol, on intraperitoneal sepsis-induced organ injury in rats. Shock. 2005;23: 88-96.

35.Mittal M, Siddiqui MR, Tran K, Reddy SP, Malik AB. Reactive oxygen species in inflammation and tissue injury. Antioxid Redox Signal. 2014;20: 1126-1167.

36.Vuppalanchi R, Ghabril M, Chalasani N, Juluri R, Bell LN, Klaunig JE, et al. Oxidative stress in chronic liver disease: Relationship between peripheral and hepatic measurements. Am J Med Sci. 2011;342: 314 317.

37. Topal T, Oter S, Korkmaz A, Sadir S, Metinyurt G, Korkmazhan ET, et al. Exogenously administered and endogenously produced melatonin reduce hyperbaric oxygen-induced oxidative stress in rat lung. Life Sci. 2004;75: 461-467.

38.Brien XM, Biron BM, Reichner JS. Consequences of extracellular trap formation in sepsis. Curr Opin Hematol. 2017;24: 66.

39.Tsao CM, Ho ST, Chen A, Wang JJ, Tsai SK, Wu CC, et al. Propofol ameliorates liver dysfunction and inhibits aortic superoxide level in conscious rats with endotoxic shock. Eur J Pharmacol. 2003;477: 183. 193.

40.Jaeschke H. Reactive oxygen and mechanisms of inflammatory liver injury: Present concepts. J Gastroenterol Hepatol. 2011;26: 173-179.

41. Shirahane K, Yamaguchi K, Koga K, Watanabe M, Kuroki S. Hepatic ischemia/reperfusion injury is prevented by a novel matrix metalloproteinase inhibitor, ONO-4817. Surg. 2006;139: 653-664. 